\title{
DÜBLIN
}

Technological University Dublin

ARROW@TU Dublin

\section{The effect of lauric arginate on the thermal inactivation of starved Listeria monocytogenes in sous-vide cooked ground beef}

Vijay K. Juneja

US Department of Agriculture, vijay.juneja@usda.gov

Marangeli Osoria

US Department of Agriculture

Uma Tiwari

Technological University Dublin, uma.tiwari@tudublin.ie

See next page for additional authors

Follow this and additional works at: https://arrow.tudublin.ie/schfsehart

Part of the Beef Science Commons, Food Biotechnology Commons, Food Microbiology Commons, and the Food Processing Commons

\section{Recommended Citation}

Vijay K. Juneja, Marangeli Osoria, Uma Tiwari, Xinran Xu, Chase E. Golden, Sudarsan Mukhopadhyay, Abhinav Mishra, The effect of lauric arginate on the thermal inactivation of starved Listeria monocytogenes in sous-vide cooked ground beef, Food Research International, Volume 134, 2020, 109280, ISSN 0963-9969. DOI: 10.1016/j.foodres.2020.109280.

This Article is brought to you for free and open access by the School of Food Science and Environmental Health at ARROW@TU Dublin. It has been accepted for inclusion in Articles by an authorized administrator of ARROW@TU Dublin. For more information, please contact arrow.admin@tudublin.ie, aisling.coyne@tudublin.ie, gerard.connolly@tudublin.ie.

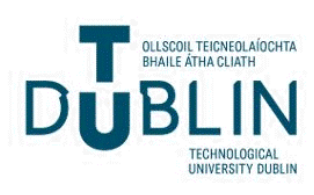




\section{Authors}

Vijay K. Juneja, Marangeli Osoria, Uma Tiwari, Xinran Xu, Chase E. Golden, Sudarsan Mukhopadhyay, and Abhinav Mishra 


\title{
The effect of lauric arginate on the thermal inactivation of starved Listeria monocytogenes in sous-vide cooked ground beef
}

\author{
Vijay K. Juneja ${ }^{\mathrm{a}, *}$, Marangeli Osoria ${ }^{\mathrm{a}}$, Uma Tiwari ${ }^{\mathrm{b}}$, Xinran $\mathrm{Xu}^{\mathrm{c}}$, Chase E. Golden ${ }^{\mathrm{c}}$, \\ Sudarsan Mukhopadhyay ${ }^{\mathrm{a}}$, Abhinav Mishra ${ }^{\mathrm{c}}$ \\ ${ }^{a}$ U.S. Department of Agriculture, Agricultural Research Service, Eastern Regional Research Center, 600 East Mermaid Lane, Wyndmoor, PA 19038, USA \\ ${ }^{\mathrm{b}}$ School of Food Science and Environmental Health, Technological University Dublin, City Campus, Dublin, Ireland \\ ${ }^{\mathrm{c}}$ Department of Food Science and Technology, University of Georgia, Athens, GA, USA
}

\section{A R T I C L E I N F O}

\section{Keywords:}

Beef

Lauric arginate

L. monocytogenes

Sous-vide

Thermal inactivation

\begin{abstract}
A B S T R A C T
The aim of this study was to examine the efficacy of lauric arginate (LAE, $1000 \mathrm{ppm}-3000 \mathrm{ppm}$ ) as an assisting tool to reduce starved Listeria monocytogenes population in ground beef following sous-vide processing at different temperatures $\left(55-62.5^{\circ} \mathrm{C}\right)$. Ground beef mixed with LAE was vacuum sealed and a laboratory water bath was used for sous-vide cooking. Loglinear and Weibull models were fit to the survival microbial population and the D and Z-values were determined at $55-62.5^{\circ} \mathrm{C}$. Calculated D-values ranged from 33.62 to 3.22 min at temperature $55-62.5^{\circ} \mathrm{C}$. LAE at higher concentration is an effective antimicrobial to increase the inactivation of the pathogen in sous-vide cooking. With the addition of LAE, D-values at 55 and $62.5^{\circ} \mathrm{C}$ determined by the Loglinear model decreased from 31.86 to $2.28 \mathrm{~min}$ (LAE $1000 \mathrm{ppm}$ ) and 16.71 to $0.56 \mathrm{~min}$ (LAE $3000 \mathrm{ppm}$ ), respectively; whereas the D-values at 55 to $62.5{ }^{\circ} \mathrm{C}$ determined by the Weibull model were 44.26 and 2.09 min (LAE $1000 \mathrm{ppm}$ ) and 22.71 and $1.60 \mathrm{~min}$ (LAE $3000 \mathrm{ppm}$ ), respectively. This study shows that sous-vide processing of ground beef supplemented with higher concentration of LAE effectively inactivates L. monocytogenes and thus, helps increase the microbiological safety and product quality.
\end{abstract}

\section{Introduction}

Listeria monocytogenes is a ubiquitous foodborne pathogen that remains a concern for food processors due to its psychrotrophic behavior. The pathogen is widely distributed in the environment (e.g., soil, water, silage, etc.) and can find its way into the food processing plant and cross-contaminates food contact surfaces and other processing equipment (Tiwari et al., 2015). L. monocytogenes grows and survives at a wide temperature range, from -0.4 to $45{ }^{\circ} \mathrm{C}$ (ICMSF, 1996), and if ingested in contaminated foods, can cause listeriosis (food poisoning) outbreaks in humans (WHO/FAO, 2004). The impact of Listeria on food related diseases is widely reported. Todd and Notermans (2011) conducted a surveillance study to monitor the increase in outbreaks of listeriosis among developed countries over decades, with the incidence rate of human infections ranging from 0.3 to 1.3 per 100,000 population.

Thermal processing remains one of the most widely employed techniques for ensuring the food safety profile of a range of solid foods, including meat. One of the thermal processing techniques is sous-vide processing, i.e., food products packaged under vacuum are cooked under controlled conditions of temperature and time. This process of cooking is used to prevent losses of water and flavors, which helps to make pasteurized, ready-to-eat (RTE), refrigerated foods more desirable and to extend the shelf life of the products. However, adverse thermal impact on the quality of meat is often debated. As such, negative impacts on the quality of food can be reduced by manipulating the food formulation factors and thereby, rendering the pathogen more sensitive to the lethal effect of heat.

Lauric arginate (LAE; N-lauroyl-L-arginine ethyl ester monohydrochloride) is a cationic surfactant derived from lauric acid, L-arginine and ethanol (Ruckman, Rocabayera, Borzelleca, \& Sandusky, 2004). This food grade antimicrobial agent/preservative has been approved by the United States-Food and Drug Administration (US-FDA, 2005) and the European Food Safety Authority (EFSA, 2007) as a 'generally recognized as safe' (GRAS) food additive, to use in foods such as RTE meat products (Ruckman, Rocabayera, Borzelleca, Sandusky, 2004). In the human body, it is rapidly metabolized to naturally occurring amino acids (dietary components), arginine and ornithine, and is thus known to be non-toxic (Hawkins, Rocabayera, Ruckman, Segret, \& Shaw, 2009). It has a broad spectrum of antimicrobial activity and is

\footnotetext{
* Corresponding author.

E-mail address: vijay.juneja@usda.gov (V.K. Juneja).
} 
widely used in the food and food packaging industries to guard against the hazards associated with both Gram-positive and Gram-negative bacteria (Becerril, Manso, Nerin, \& Gómez-Lus, 2013; Coronel-Leon et al., 2016), as well as molds. While alterations in the cytoplasmic membrane and external membrane were found in LAE treated Gramnegative Salmonella Typhimurium, alterations in cell membrane and cytoplasm were observed in Gram-positive Staphylococcus aureus. Nevertheless, disturbance in membrane potential and cell structure can lead to loss of cell viability, without causing lysis or disruption of treated cells (Rodriguez, Seguer, Rocabayera, \& Manresa, 2004). Its effectiveness is well documented in the reduction of $L$. monocytogenes (Porto-Fett et al., 2010). Based on the mode of actions of different antimicrobials, the efficacy of LAE in combination with other preservatives has been reported to exhibit additive or synergistic effects against foodborne pathogens, such as Salmonella spp., L. monocytogenes, and Escherichia coli (Martin et al., 2009; Brandt et al., 2010; Stopforth, Visser, Zumbrink., van Dijk, \& Bontenbal, 2010; Noll, Prichard, Khaykin, Sinko, \& Chikindas, 2012; Soni, Desai, Oladunjoye, Skrobot, \& Nannapaneni, 2012; Theinsathid, Visessanguan, Kruenate, Kingcha, \& Keeratipibul, 2012). In a toxicological animal study with different levels of LAE, Ruckman et al. (2004) concluded that there was no sign of neurotoxicity even at high levels of $\operatorname{LAE}(50,000 \mathrm{ppm})$, helping to confirm the safety of LAE as a food additive.

Microbial starvation commonly exists in the food industry because usage of water and sanitizer in cleaning and sanitizing on food contact surfaces generally creates an inconducive environment for microorganisms. Exposure to nutrient shortages and chemical treatments may increase microorganisms' resistance to heating processes. For example, heat resistance of starved $L$. monocytogenes in flask of Trypticase Soy Broth with $0.6 \%$ yeast extract followed by treatment of heat shock was observed to increase (Lou \& Yousef, 1997). The ability of pathogens to increase microbial resistance can result in reducing effectiveness of inactivation and preservation methods. Therefore, evaluating the efficiency of inactivation parameters on starved bacterial cells can help the food industry improve processing and ensure food safety and quality.

To our knowledge, there are no published studies on the thermal death time values of L. monocytogenes in sous-vide processed ground beef supplemented with LAE. Accordingly, the goal of this study was to determine the efficacy of LAE in rendering L. monocytogenes more sensitive to the lethal effect of heat under conditions that occur in the retail food industry. The thermal death time values of $L$. monocytogenes at $55,57.5,60$ and $62.5^{\circ} \mathrm{C}$ quantified in the current study can be used to validate the sous-vide cooking of beef to eliminate the pathogen and enhance the microbiological safety of the product during its intended shelf-life.

\section{Material and methods}

\subsection{Bacterial cultures}

Five L. monocytogenes strains that were isolated from human clinical cases (Scott A), a hot dog outbreak (H7762), steer/heifer (MF27137), ground chicken (MF38521), and fresh pork sausage (MF46869) were used in this study. Stock cultures were maintained at $-80{ }^{\circ} \mathrm{C}$ in brain heart infusion broth (BHI; Labline-Thermo Scientific, Melrose Park, IL) with $20 \%$ v/v glycerol (Sigma-Aldrich, St. Louis, MO). The strains were thawed and individually grown by transferring $0.1 \mathrm{ml}$ of culture to $10 \mathrm{ml} \mathrm{BHI}$ broth tubes and incubating for $24 \mathrm{~h}$ at $37^{\circ} \mathrm{C}$. A second transfer into fresh BHI tubes was made and BHI slants were streaked for each strain. Both slants and broth tubes were incubated for $24 \mathrm{~h}$ at $37^{\circ} \mathrm{C}$ and then maintained at $4{ }^{\circ} \mathrm{C}$. Biweekly culture transfers were made from the slants which were initiated monthly from the frozen stocks.

\subsection{Preparation and starvation of inoculum}

Overnight cultures $(0.1 \mathrm{ml})$ were grown in BHI broth $(50 \mathrm{ml})$ in
Table 1

Thermal inactivation kinetics in ground beef supplemented various concentrations of $\mathrm{LAE}^{1}$ at different temperatures.

\begin{tabular}{|c|c|c|c|c|c|c|}
\hline Temperature $\left({ }^{\circ} \mathrm{C}\right)$ & $\begin{array}{l}\text { D value } \\
\text { Ll (min) }\end{array}$ & $\begin{array}{l}\mathrm{T} 4 \mathrm{D}(\mathrm{min}) \\
\mathrm{Ll}^{2}\end{array}$ & $\begin{array}{l}\mathrm{D} \\
\text { value } \\
\mathrm{Wb}^{3} \\
(\mathrm{~min})\end{array}$ & $\begin{array}{l}\text { T4D (min) } \\
\mathrm{Wb}\end{array}$ & $\begin{array}{l}\mathrm{z} \text { value } \\
\left({ }^{\circ} \mathrm{C}\right) \mathrm{Ll}\end{array}$ & $\begin{array}{l}\mathrm{z} \text { value } \\
\left({ }^{\circ} \mathrm{C}\right) \\
\mathrm{Wb}\end{array}$ \\
\hline \multicolumn{7}{|l|}{ Control } \\
\hline 55 & 33.62 & 134.48 & 43.74 & 174.96 & & \\
\hline 57.5 & 14.05 & 50.20 & 12.84 & 51.36 & & \\
\hline 60 & 5.88 & 23.53 & 7.76 & 31.04 & & \\
\hline 62.5 & 3.22 & 12.87 & 4.47 & 17.89 & 7.28 & 7.84 \\
\hline \multicolumn{7}{|l|}{ LAE 1000 ppm } \\
\hline 55 & 31.86 & 127.44 & 44.26 & 177.04 & & \\
\hline 57.5 & 12.46 & 49.84 & 15.22 & 60.88 & & \\
\hline 60 & 3.79 & 15.18 & 3.93 & 15.73 & & \\
\hline 62.5 & 2.28 & 9.12 & 2.09 & 8.36 & 6.33 & 5.48 \\
\hline \multicolumn{7}{|l|}{ LAE 3000 ppm } \\
\hline 55 & 16.71 & 66.84 & 22.71 & 90.84 & & \\
\hline 57.5 & 9.20 & 36.80 & 8.39 & 33.55 & & \\
\hline 60 & 1.16 & 4.66 & 1.17 & 4.66 & & \\
\hline 62.5 & 0.56 & 2.25 & 1.60 & 6.4 & 4.70 & 5.80 \\
\hline
\end{tabular}

1 LAE: lauric arginate.

2 Ll: Loglinear.

3 Wb: Weibull.

Table 2

Shape parameter values obtained from the Weibull distribution for treated and untreated ground beef with LAE at different temperatures.

\begin{tabular}{llll}
\hline \multirow{2}{*}{ Temperature $\left({ }^{\circ} \mathrm{C}\right)$} & \multicolumn{3}{l}{ Shape parameter $(\beta)$} \\
\cline { 2 - 4 } & Control & LAE $1000 \mathrm{ppm}$ & LAE $3000 \mathrm{ppm}$ \\
\hline 55 & 1.27 & 1.33 & 1.42 \\
57.5 & 0.93 & 1.18 & 0.94 \\
60 & 1.26 & 1.04 & 1.23 \\
62.5 & 1.95 & 0.89 & 0.28 \\
\hline
\end{tabular}

$\beta<1$ : concave shaped curves; $\beta>1$ : convex shaped curves; $\beta=1$ : linear shaped; LAE: lauric arginate.

$250 \mathrm{ml}$ flasks at $37{ }^{\circ} \mathrm{C}$ for $18 \mathrm{~h}$. The cultures were centrifuged twice at $4696 \times \mathrm{g}$ for $15 \mathrm{~min}$ at $4{ }^{\circ} \mathrm{C}$ with the pellet being washed once in $0.1 \%$ (w/v) peptone water (PW; Becton, Dickinson \& Co., Sparks, MD) and finally suspended in $10 \mathrm{ml}$ of Butterfield Phosphate Buffer (Neogen Corp., Lansing, MI; Juneja, Gonzales-Barron, Butler, Yadav, \& Friedman, 2013). These new cultures were incubated at $37{ }^{\circ} \mathrm{C}$ for $24 \mathrm{~h}$ for starvation. The starved cultures were centrifuged and washed as described above and then suspended in $2 \mathrm{ml}$ of $0.1 \% \mathrm{PW}$. These $2 \mathrm{ml}$ cultures were combined in a sterile conical vial and vortexed for a minute to produce a five-strain cocktail of $L$. monocytogenes (7-8 $\log _{10}$ $\mathrm{CFU} / \mathrm{ml})$.

\subsection{Sample preparation}

Ground beef (73\% lean) procured from a local market was divided into 50-g portions. The portions were mixed with 1000 or $3000 \mathrm{ppm}$ LAE (Ethyl Lauroyl Arginate $\mathrm{HCl}$; Mirenat-GA; Vedeqsa, Barcelona, Spain) using a KitchenAid mixer (model K5SSDWH, St. Joseph, MI) while the control samples were prepared without addition of lauric arginate. All samples were stored frozen for about $60 \mathrm{~d}$ until further use. Thawed 50-g sample bags were inoculated $(0.1 \mathrm{ml})$ with the cocktail inoculum and thoroughly mixed both manually and with a Seward stomacher 400 (Seward, UK) for $2 \mathrm{~min}$. Three-gram samples were aseptically transferred into filter stomacher bags (Nasco Whirl- 

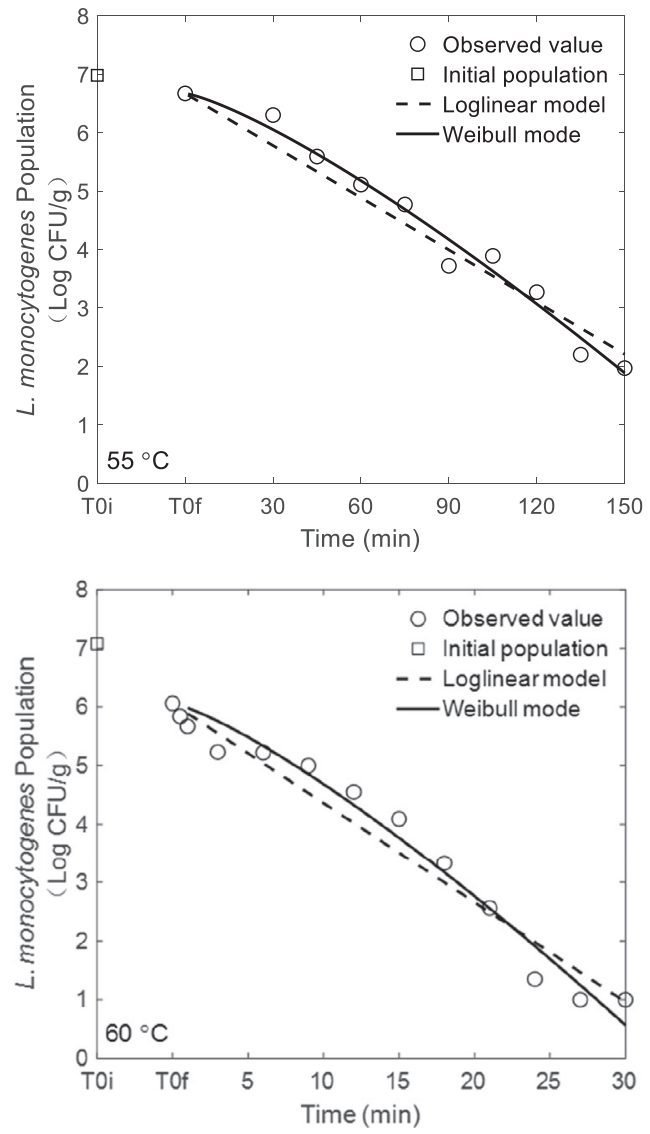
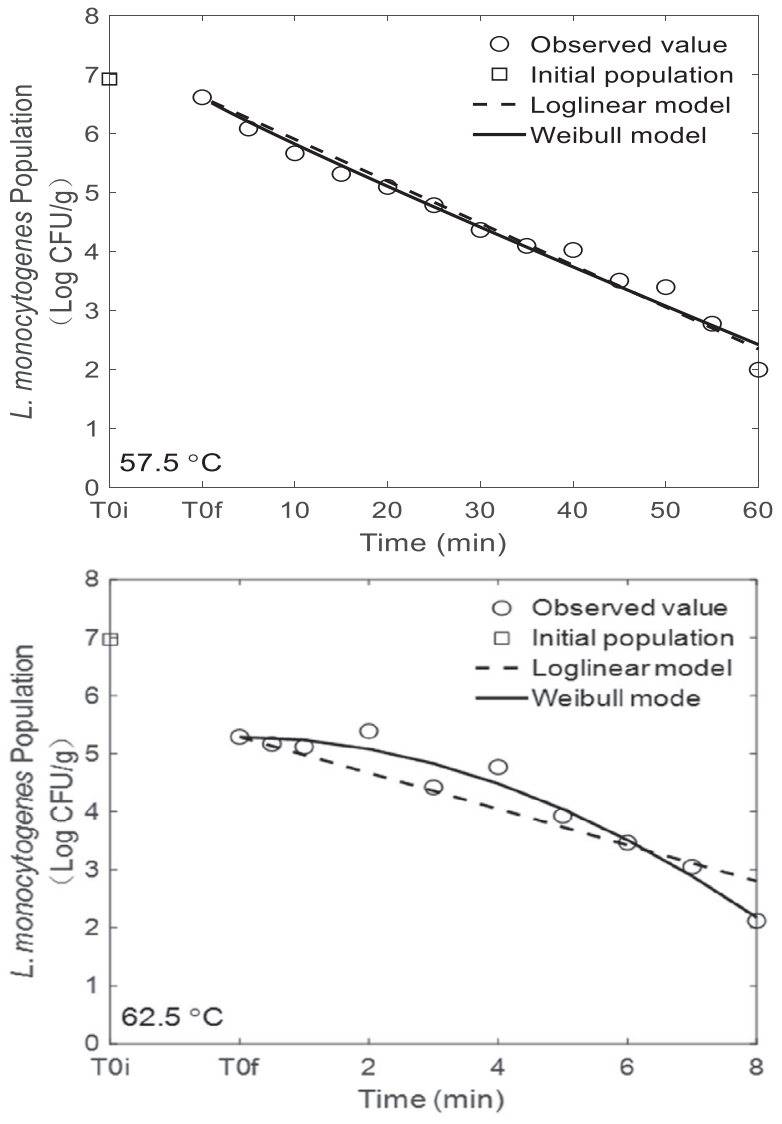

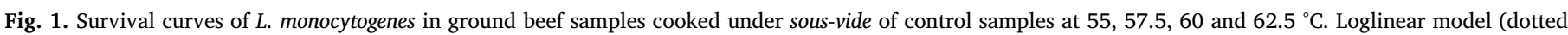
line) and Weibull (solid line) model.

Pak, Fort Atkinson, WI), pressed into a thin layer and sealed using a vacuum sealer (model A300/16, Multivac Inc., Kansas City, MO).

\subsection{Sous-vide cooking and thermal treatment}

To simulate the cooking of rare roast beef as performed in the food industry, 3-g meat sample bags were placed in a wire rack and fully immersed in a temperature-controlled water bath (Thermo NESLAB RTE-17, Neslab Instruments, Inc., Newington, NH). The temperatures of the water and the meat samples were monitored using a type $\mathrm{K}$ thermocouple (Omega Engineering Inc., Stamford, CT) and recorded using a temperature data logger (SPI50, Dickson, Addison, IL). For the meat samples, the thermocouple was inserted in the center of an uninoculated meat bag. The temperature of the water bath was programmed to increase linearly from $23{ }^{\circ} \mathrm{C}$ to four specific target temperatures $(55$, $57.5,60$ and $62.5{ }^{\circ} \mathrm{C}$ ) in $1 \mathrm{~h}$. Meat sample bags were pulled at predetermined times once the target temperature was reached. The bags were subsequently immersed in an ice/water slurry and analyzed within $30 \mathrm{~min}$. The total heating times ranged from 60 to $150 \mathrm{~min}$ at $55{ }^{\circ} \mathrm{C}, 48$ to $60 \mathrm{~min}$ at $57.5^{\circ} \mathrm{C}, 1.5$ to $30 \mathrm{~min}$ at $60^{\circ} \mathrm{C}$, and 1.5 to $8 \mathrm{~min}$ at $62.5^{\circ} \mathrm{C}$ and sampling frequency ranged from every $10-30 \min 55^{\circ} \mathrm{C}$ to 0.25 to $1 \mathrm{~min}$ at $62.5^{\circ} \mathrm{C}$.

\subsection{Microbiological analysis and enumeration}

Each heat-treated sample bag was opened aseptically, combined with $3 \mathrm{ml}$ of $0.1 \% \mathrm{PW}$ and vigorously mixed for $2 \mathrm{~min}$ using a stomacher (Bag Mixer 100 Mini Mix, Interscience, St. Nom, France). After 10-fold serial dilutions, $100 \mu \mathrm{l}$ were spread onto Tryptic Soy Agar (TSA; Becton, Dickinson \& Co., Sparks, MD) plates. The plates were left for $2 \mathrm{~h}$ and overlaid afterwards with Difco Oxford Medium Base with Difco
Modified Oxford Supplement (MOX; Becton, Dickinson \& Co., Sparks, $\mathrm{MD})$. Colonies were enumerated [colony forming units (CFU) $/ \mathrm{g}$ ] after $48 \mathrm{~h}$ of incubation at $30^{\circ} \mathrm{C}$. All experiments were independently performed twice.

\subsection{Microbial inactivation models}

Two inactivation models (Log-linear and Weibull) were fitted to the changes in microbial population by using the MATLAB (version 2018b, The MathWorks, Inc. Natick, MA). Log-linear is a simple first-order inactivation model that shows exponential inactivation by using the following equation:

$y=y_{0}-\frac{t}{D}$

where $y$ represents observed population of $L$. monocytogenes (Log CFU/ $\mathrm{g}$ ) and $y_{0}$ represents initial population of L. monocytogenes (Log CFU/g); $t$ represents time and $D$, decimal reduction "D-value", represents the inactivation time (min) at a given temperature.

The Weibull model is an inactivation model that demonstrates the decline in microbial numbers as a cumulative distribution of heat lethality. The Weibull model includes two model parameters, shape $\beta$ and scale $D$. The scale parameter accounts for various shaped survival curves such as concave $(\beta<1)$, convex $(\beta>1)$ or linear $(\beta=1)$ shaped curves and decimal reduction (D-value) time (min) taken to achieve a $1 \log$ CFU reduction in microbial population:

$y=y_{0}-[t / D]^{\beta}$

The Z-values were determined as the negative inverse slope of the $\log \mathrm{D}$-values versus temperature: 

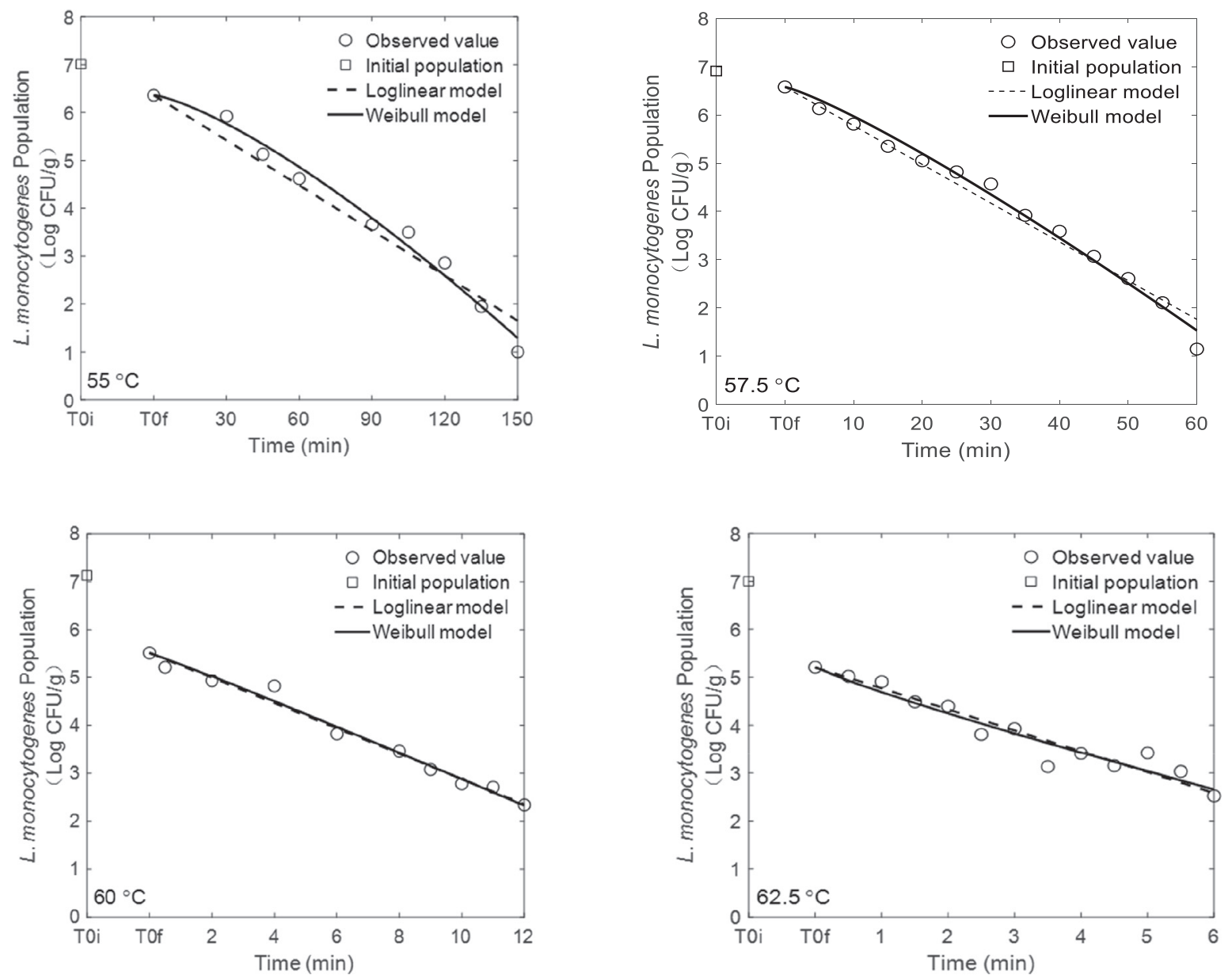

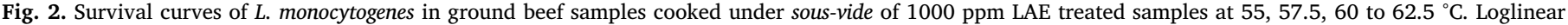
model (dotted line) and Weibull (solid line) model.

$\log (D)=\log \left(D_{0}\right)-\frac{t}{Z}$

\subsection{Model evaluation \& statistical analysis}

All statistical analyses were performed using MATLAB. The performances of inactivation models were compared using root mean square root (RMSE), coefficient of determination $\left(\mathrm{R}^{2}\right)$ and sum of squared error (SSE). All values were calculated with $95 \%$ confidence intervals.

\section{Results}

\subsection{Microbial inacitvation}

The efficacy of adding 1000 and 3000 ppm LAE to ground beef on thermal inactivation of L. monocytogenes following sous-vide beef processing at various temperatures was studied. The results were shown in Table 1. As expected, the D-values obtained from the Loglinear and Weibull model both decreased when temperature increased for the control and LAE-treated samples. For the Weibull model, the D-value of control samples decreased from 43.74 to $12.84 \mathrm{~min}$ at 55 to $57.5{ }^{\circ} \mathrm{C}$, and further reduced to $7.76 \mathrm{~min}$ at $60{ }^{\circ} \mathrm{C}$ and $4.47 \mathrm{~min}$ at $62.5^{\circ} \mathrm{C}$. The addition of $1000 \mathrm{ppm}$ of LAE added into samples slightly decreased the $\mathrm{D}$-value of $L$. monocytogenes at all temperatures, except that at $55^{\circ} \mathrm{C}$ and $57.5{ }^{\circ} \mathrm{C}$ in the Weibull model. The Weibull model showed the D-values of $44.26 \mathrm{~min}\left(55^{\circ} \mathrm{C}\right)$ and $15.22 \mathrm{~min}\left(57.5^{\circ} \mathrm{C}\right)$ in samples supplemented with 1000 ppm LAE, which were slightly higher than the D-value in control samples.
Compared to the control samples, D-values further decreased when the level of LAE in samples increased to $3000 \mathrm{ppm}, 22.71 \mathrm{~min}$ at $55^{\circ} \mathrm{C}$ in the Weibull model compared to $43.74 \mathrm{~min}$ at $55{ }^{\circ} \mathrm{C}$ that was estimated for the control samples. The decreasing trend of the D-value of $L$. monocytogenes with addition of LAE was noticed in the log-linear model as well. The D-value was calculated as $12.87 \mathrm{~min}$ at $62.5^{\circ} \mathrm{C}$ of control sample while a reduced D-value of $9.12 \mathrm{~min}$ was calculated for samples supplemented with $1000 \mathrm{ppm}$ LAE at the same temperature. Furthermore, the D-value decreased to $2.25 \mathrm{~min}$ at $62.5{ }^{\circ} \mathrm{C}$ when the level of LAE increased to $3000 \mathrm{ppm}$. LAE treatment showed an antimicrobial ability which reflected on the z-value as well. For the Loglinear model, the z-value of control was estimated at $7.28^{\circ} \mathrm{C}$ while it decreased to $6.33{ }^{\circ} \mathrm{C}$ when $1000 \mathrm{ppm}$ LAE was added. With $3000 \mathrm{ppm}$ $\mathrm{LAE}$ treatment, the z-value further reduced to $4.70{ }^{\circ} \mathrm{C}$. Similarly, for the Weibull model, the z-values were estimated to be $7.84{ }^{\circ} \mathrm{C}, 5.48{ }^{\circ} \mathrm{C}$, and $5.80{ }^{\circ} \mathrm{C}$ for the control samples, $1000 \mathrm{ppm}$ and $3000 \mathrm{ppm}$ LAE, respectively.

Table 2 shows the shape parameter " $\beta$ " of Weibull model fitted to $L$. monocytogenes population during sous-vide processing at 55, 57.5, 60 and $62{ }^{\circ} \mathrm{C}$. The survival curves were mostly convex $(\beta>1)$ shaped for the control samples (Fig. 1, Fig. 2, Fig. 3), with the exception of $57.5^{\circ} \mathrm{C}$. For the samples treated with $1000 \mathrm{ppm}$ LAE, the survival curves were convex for temparature from $55^{\circ} \mathrm{C}$ to $60^{\circ} \mathrm{C}$, but for temperature $62.5^{\circ} \mathrm{C}$ curve was concave. The survival curves for 3000 ppm LAE exhibited a different trend. For temperature $55{ }^{\circ} \mathrm{C}$ and $60{ }^{\circ} \mathrm{C}$, the survival curves were convex while the opposite for temperature $57.5^{\circ} \mathrm{C}$ and $62.5^{\circ} \mathrm{C}$. The $\beta$ values were in the $0.28-1.95$ range, and very close to 1 in several cases, which indicates that there was not very strong concave or convex 

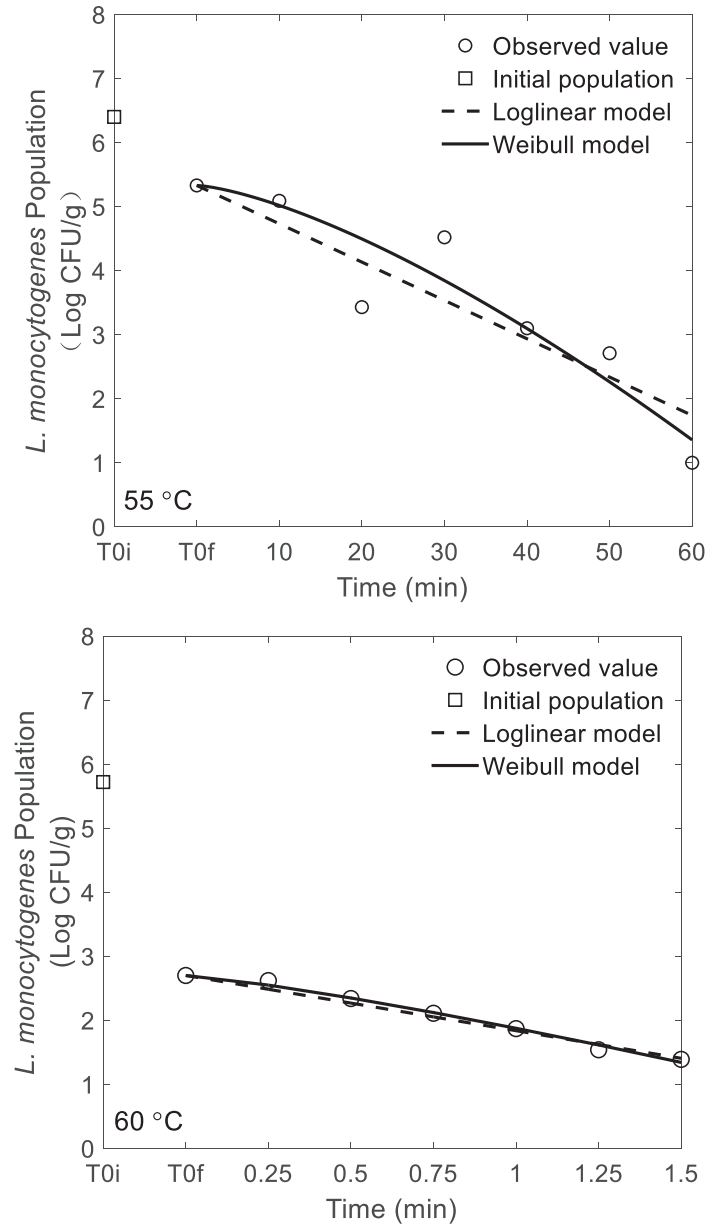
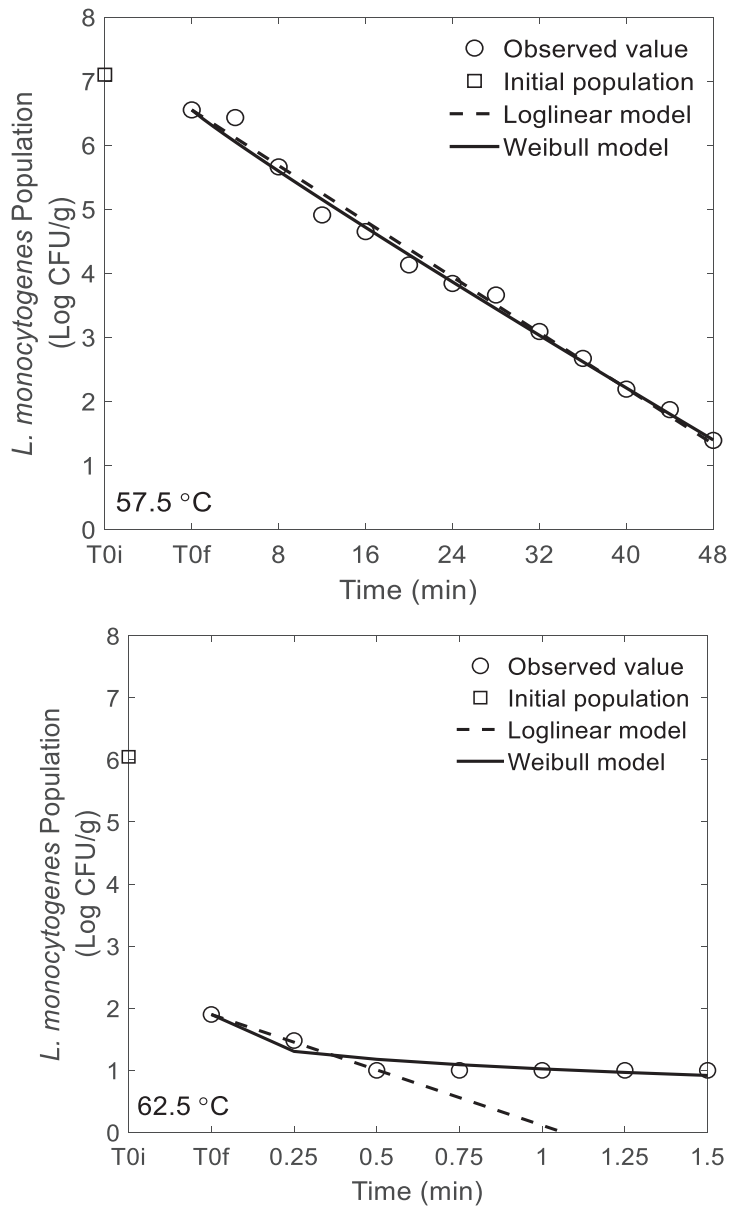

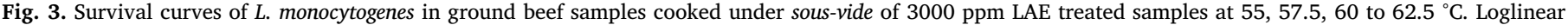
model (dotted line) and Weibull (solid line) model.

Table 3

Comparison of the goodness of fit of the Loglinear and Weibull models for the survival curves of L. monocytogenes in ground beef with added LAE at 55 to $62.5^{\circ} \mathrm{C}$.

\begin{tabular}{|c|c|c|c|c|c|c|}
\hline & \multicolumn{3}{|c|}{ Log Linear } & \multicolumn{3}{|l|}{ Weibull } \\
\hline & Control & $\begin{array}{l}\text { LAE } \\
1000 \text { ppm }\end{array}$ & $\begin{array}{l}\text { LAE } \\
3000 \text { ppm }\end{array}$ & Control & $\begin{array}{l}\text { LAE } \\
1000 \text { ppm }\end{array}$ & $\begin{array}{l}\text { LAE } \\
3000 \text { ppm }\end{array}$ \\
\hline \multicolumn{7}{|c|}{ Temperature $\left(55^{\circ} \mathrm{C}\right)$} \\
\hline RMSE & 0.33 & 0.36 & 0.62 & 0.24 & 0.23 & 0.62 \\
\hline$R^{2}$ & 0.96 & 0.96 & 0.83 & 0.98 & 0.98 & 0.86 \\
\hline SSE & 0.98 & 1.04 & 2.31 & 0.47 & 0.38 & 1.92 \\
\hline \multicolumn{7}{|c|}{ Temperature $\left(57.5^{\circ} \mathrm{C}\right)$} \\
\hline RMSE & 0.20 & 0.19 & 0.17 & 0.20 & 0.19 & 0.16 \\
\hline$R^{2}$ & 0.98 & 0.99 & 0.99 & 0.98 & 0.99 & 0.99 \\
\hline SSE & 0.48 & 0.38 & 0.35 & 0.44 & 0.38 & 0.29 \\
\hline \multicolumn{7}{|c|}{ Temperature $\left(60{ }^{\circ} \mathrm{C}\right)$} \\
\hline RMSE & 0.38 & 0.16 & 0.08 & 0.33 & 0.16 & 0.05 \\
\hline$R^{2}$ & 0.96 & 0.98 & 0.98 & 0.97 & 0.98 & 0.99 \\
\hline SSE & 1.77 & 0.19 & 0.03 & 1.19 & 0.19 & 0.01 \\
\hline \multicolumn{7}{|c|}{ Temperature $\left(62.5^{\circ} \mathrm{C}\right)$} \\
\hline RMSE & 0.42 & 0.23 & 0.02 & 0.23 & 0.23 & 0.13 \\
\hline$R^{2}$ & 0.86 & 0.93 & 0.99 & 0.96 & 0.93 & 0.90 \\
\hline SSE & 1.58 & 0.59 & 0.02 & 0.41 & 0.59 & 0.08 \\
\hline
\end{tabular}

RMSE: root mean square root; SSE: sum of squared error

curve. These $\beta$ values for the Weibull model also suggest that a Loglinear model may generally define the inactivation pattern of $L$. monocytogenes in our studies very well.

Table 3 presents the goodness of fit statistics for all the fitted survival curves. Overall, the Loglinear and Weibull models showed a good fit with low RMSE (0.13 to 0.42) for all treatment except samples supplemented with $3000 \mathrm{ppm}$ LAE at $55{ }^{\circ} \mathrm{C}(0.62)$. A similar trend was observed for $\mathrm{R}^{2}$ values for both Loglinear and Weibull model, respectively. $\mathrm{R}^{2}$ values were ranged from 0.90 to 0.99 with the exception that the $\mathrm{R}^{2}$ values of samples added with $3000 \mathrm{ppm}$ LAE at $55{ }^{\circ} \mathrm{C}$ were 0.83 for the Loglinear model and 0.86 for the Weibull model, respectively. In addition, control samples at $62.5{ }^{\circ} \mathrm{C}$ showed a $\mathrm{R}^{2}$ value as 0.86 . In general, the SSE of Loglinear and Weibull survival curves showed relatively higher values, ranging from 0.02 to 2.31, compared to RMSE. The samples with addition of $1000 \mathrm{ppm}$ and $3000 \mathrm{ppm}$ LAE were identified with the SSE of 1.04 and 2.31, respectively, for the Loglinear model while control sample illustrated the SSE as 1.77 for the Loglinear model. Similar trend was found in the Weibull model that the SSE of sample supplemented with 3000 ppm LAE at $55^{\circ} \mathrm{C}$ was 1.92 and control sample at $60{ }^{\circ} \mathrm{C}$ was 1.19 .

\section{Discussion}

The results showed that $1000 \mathrm{ppm}$ and $3000 \mathrm{ppm}$ LAE aided in reducing $L$. monocytogenes population densities during sous-vide processing of ground beef at different temperatures (55, 57.5, 60 and $62.5^{\circ} \mathrm{C}$ ). The inactivation models (Loglinear and Weibull) fiited to the survival curves showed the models fit the data well. A decreasing trend of D-values was observed with the aid of LAE treatment (1000 ppm and $3000 \mathrm{ppm}$ ) at all temperature, except that at 55 and $57.5^{\circ} \mathrm{C}$ the samples supplement with $1000 \mathrm{ppm}$ LAE showed slightly higher D-values in the Weibull model. In the Loglinear model, the D-values of samples treated 
with $1000 \mathrm{ppm}$ LAE at 55 and $57.5^{\circ} \mathrm{C}$ were slightly lower comparing to the D-values of control sample. The results indicated that lower concentration of LAE (1000 ppm) may not have strong antimicrobial ability under lower temperatures $\left(55\right.$ and $57.5^{\circ} \mathrm{C}$ ). A significant decrease of Dvalues between samples with $3000 \mathrm{ppm}$ LAE treatment and control samples was observed in both Loglinear and Weibull model at all temperatures, which illustrated that $L$. monocytogenes was more sensitive to higher concentration of LAE even under relatively low temperatures ( 55 and $57.5{ }^{\circ} \mathrm{C}$ ). In another study, frankfurters treated with $5,000 \mathrm{ppm}$ of LAE resulted in about 2-log reduction of $L$. monocytogenes within $48 \mathrm{~h}$ (Taormina \& Dorsa, 2009), which supported the bactericidal effect of LAE on $L$. monocytogenes.

Loglinear model and Weibull model were used to fit the survial curves for temperature from $55{ }^{\circ} \mathrm{C}$ to $62.5{ }^{\circ} \mathrm{C}$ with control samples and LAE treated samples. Overall, both models fit the data well except control samples at $62.5^{\circ} \mathrm{C}$ where the Weibull model illustrated a better fit compared to the Loglinear model by having a greater $\mathrm{R}^{2}$ value.

The D-values of starved $L$. monocytogenes cells in control samples were reduced from $33.6 \mathrm{~min}$ at $55{ }^{\circ} \mathrm{C}$ to $5.88 \mathrm{~min}$ at $60{ }^{\circ} \mathrm{C}$. Similar results showed that the D-values of starved $L$. monocytogenes decreased from $24.61 \mathrm{~min}$ at $56.3{ }^{\circ} \mathrm{C}$ to $2.83 \mathrm{~min}$ at $60{ }^{\circ} \mathrm{C}$ during heat treatment for bologna (Grosulescu, Juneja, \& Ravishankar, 2011). The D-value of non-starved L. monocytogenes was obtained for $3.2 \mathrm{~min}$ at $55{ }^{\circ} \mathrm{C}$ and $0.15 \mathrm{~min} 60^{\circ} \mathrm{C}$ in ground beef follow by sous-vide cooking (Bolton et al., 2000). A significant increase of the D-values was observed between non-starved and starved $L$. monocytogenes cells, which indicated that starved L. monocytogenes cells have higher heat resistance.

Knowledge of the thermal inactivation kinetics of inoculating pathogens in thermally processed meat products is necessary to design adequate thermal processes and to ensure the elimination of pathogens.

The current study suggests that the addition LAE in ground beef followed by sous-vide processing effectively controlled $L$. monocytogenes survial and the fitted inactivation models provides an understanding of thermal resistance behavior. Higher concentration of LAE increased the sensitivity of the L. monocytogenes to heat, and thus, minimizing any adverse effect which is essential for product quality. Decimal reduction time values obtained in the present study cannot be placed into context with previous studies due to the unavailability of published research on heat inactivation of $L$. monocytogenes in beef supplemented with LAE. LAE is proven to have anti-microbial activity in several studies. For example, in a study provided by Porto-Fett et al. (2010), when frankfurters were treated with 22 or 44 ppm LAE, L. monocytogenes levels were reduced by $2.0 \log \mathrm{CFU} /$ package within $2 \mathrm{~h}$.

\section{Conclusions}

Supplementing beef with 1000 ppm and 3000 ppm LAE followed by sous-vide processing at different temperatures showed a greater reduction in L. monocytogenes population when compared to a control. The Loglinear inactivation model as well as the Weibull inactivation model was fitted to survival curves and showed an overall good model fit for all the samples. The D-values significantly decreased among all samples (untreated and treated samples) with increasing temperatures. This study shows the L. monocytogenes cells which have been starved may have higher heat resistance. Further study is needed to explore the heat resistance of starved L. monocytogenes cells. Higher concentrations of LAE in beef increased the sensitivity of the L. monocytogenes to sous-vide treatment, thereby extending the shelf-life and improving the product quality, which is desirable for food processors, regulators and consumers.

\section{Declaration of Competing Interest}

The authors have no conflict of interest.

\section{Appendix A. Supplementary data}

Supplementary data to this article can be found online at https:// doi.org/10.1016/j.foodres.2020.109280.

\section{References}

Becerril, R., Manso, S., Nerin, C., \& Gómez-Lus, R. (2013). Antimicrobial activity of Lauroyl Arginate Ethyl (LAE), against selected food-borne bacteria. Food Control, 32(2), 404-408.

Bolton, D. J., McMahon, C. M., Doherty, A. M., Sheridan, J. J., McDowell, D. A., Blair, I. S., \& Harrington, D. (2000). Thermal inactivation of Listeria monocytogenes and Yersinia enterocolitica in minced beef under laboratory conditions and in sous-vide prepared minced and solid beef cooked in a commercial retort. Journal of Applied Microbiology, 88(4), 626-632.

Brandt, A. L., Castillo, A., Harris, K. B., Keeton, J. T., Hardin, M. D., \& Taylor, T. M. (2010). Inhibition of Listeria monocytogenes by food antimicrobials applied singly and in combination. Journal of Food Science, 75, M557-M563.

Coronel-León, J., López, A., Espuny, M. J., Beltran, M. T., Molinos-Gómez, A., Rocabayera, X., \& Manresa, A. (2016). Assessment of antimicrobial activity Na-lauroyl arginate ethylester (LAE) against Yersinia enterocolitica and Lactobacillus plantarum by flow cytometry and transmission electron microscopy. Food Control, 63, 1-10.

European Food Safety Authority (EFSA). (2007). Opinion of the scientific panel on food additives, flavourings, processing aids and materials in contact with food (AFC) related to an application on the use of ethyl lauroyl arginate as a food additive. EFSA Journal, 511, 1-27.

Grosulescu, C., Juneja, V. K., \& Ravishankar, S. (2011). Effects and interactions of sodium lactate, sodium diacetate, and pediocin on the thermal inactivation of starved Listeria monocytogenes on bologna. Food Microbiology, 28(3), 440-446.

Hawkins, D. R., Rocabayera, X., Ruckman, S., Segret, R., \& Shaw, D. (2009). Metabolism and pharmacokinetics of ethyl N(alpha)-lauroyl-1-arginate hydrochloride in human volunteers. Food and Chemical Toxicology, 47, 2711-2715.

International Commission on Microbiological Specifications for Foods (ICMSF) (1996). Microorganisms in Foods 5: Microbiological characteristics of food pathogens. New York: Blackie Academic \& Professional148.

Juneja, V. K., Gonzales-Barron, U., Butler, F., Yadav, A. S., \& Friedman, M. (2013). Predictive thermal inactivation model for the combined effect of temperature, cinnamaldehyde and carvacrol on starvation-stressed multiple Salmonella serotypes in ground chicken. International journal of food microbiology, 165(2), 184-199.

Lou, Y., \& Yousef, A. E. (1997). Adaptation to sublethal environmental stresses protects Listeria monocytogenes against lethal preservation factors. Applied and Environmental Microbiology, 64, 1252-1255.

Martin E. M., Griffis, C. L., Vaughn, K. L., O'Bryan, C.A., Friedly, E.C., Marcy, J. A., ... Lary R. Y. Jr. (2009). Control of Listeria monocytogenes by lauric arginate on frankfurters formulated with and without lactate/diacetate. Journal of Food Science, 74, M237-M241.

Noll, K. S., Prichard, M. N., Khaykin, K., Sinko, P. J., \& Chikindas, M. L. (2012). The natural antimicrobial peptide subtilosin acts synergistically with glycerol monolaurate, lauric arginate and $\mathcal{E}$-poly-L-lysine against bacterial vaginosis-associated pathogens but not human lactobacilli. Antimicrobial Agents and Chemotherapy, 56, 1756-1761.

Porto-Fett, A. C. S., Campano, S. G., Smith, J. L., Oser, A., Shoyer, B., Call, J. E., \& Luchansky, J. B. (2010). Control of Listeria monocytogenes on commercially-produced frankfurters prepared with and without potassium lactate and sodium diacetate and surface treated with lauric arginate using the Sprayed Lethality in Container (SLIC) delivery method. Meat Science, 85, 312-318.

Rodriguez, E., Seguer, J., Rocabayera, X., \& Manresa, A. (2004). Cellular effects of monohydrochloride of L-arginine, $N$ (alpha)-lauroyl ethylester (LAE) on exposure to Salmonella Typhimurium and Staphylococcus aureus. Journal of Applied Microbiology, 96, 903-912.

Ruckman, S. A., Rocabayera, X., Borzelleca, J. F., \& Sandusky, C. B. (2004). Toxicological and metabolic investigations of the safety of $\mathrm{N}$ - $\alpha$-Lauroyl-l-arginine ethyl ester monohydrochloride (LAE). Food and Chemical Toxicology, 42(2), 245-259.

Soni, K. A., Desai, M., Oladunjoye, A., Skrobot, F., \& Nannapaneni, R. (2012). Reduction of Listeria monocytogenes in queso fresco cheese by a combination of listericidal and listeriostatic GRAS antimicrobials. International Journal of Food Microbiology, 155, 82-88.

Stopforth, J. D., Visser, D., Zumbrink., R., van Dijk, L., \& Bontenbal, E. W. (2010). Control of Listeria monocytogenes on cooked cured ham by formulation with a lactate-diacetate blend and surface treatment with lauric arginate. Journal of Food Protection, 73, 552-555.

Taormina, P. J., \& Dorsa, W. J. (2009). Short-term bactericidal efficacy of lauric arginate against Listeria monocytogenes present on surface of frankfurters. J. Food Prot. 72(6), 1216-1224.

Theinsathid, P., Visessanguan, W., Kruenate, J., Kingcha, Y., \& Keeratipibul, S. (2012). Antimicrobial activity of lauric arginate-coated polylactic acid films against Listeria monocytogenes and Salmonella Typhimurium on cooked sliced ham. Journal of Food Science, 77, M142-M149.

Tiwari, U., Cummins, E., Valero, A., Walsh, D., Dalmasso, M., Jordan, K., \& Duffy, G. (2015). Farm to fork quantitative risk assessment of Listeria monocytogenes contamination in raw and pasteurized milk cheese in Ireland. Risk Analysis, 35(6), 1140-1153.

Todd, E. C. D., \& Notermans, S. (2011). Surveillance of listeriosis and its causative pathogen, Listeria monocytogenes. Food Control, 22(9), 1484-1490.

US Food and Drug Administration. (2005). Agency response letter GRAS Notice. No. GRN 000164. Spring, Maryland. Accessed 20 March 2019.

World Health Organization \& Food and Agriculture Organisation of the United Nations (WHO/ FAO). (2004). Risk assessment of Listeria monocytogenes in ready-to-eat foods: interpretative summary. https://apps.who.int/iris/handle/10665/42874 Accessed 20 March 2019. 